\title{
ANALISIS VARIANS BIAYA OPERASIONAL DALAM MENGUKUR EFEKTIVITAS PENGENDALIAN BIAYA OPERASIONAL PADA KANTOR WILAYAH VI PT. PEGADAIAN (PERSERO) MAKASSAR
}

\author{
Rustan1, Muttiarni2, Idra Wahyuni3 \\ 1,2,3 Universitas Muhammadiyah Makassar \\ e-mail: 1rustan2011@gmail.com, 2muttiani@unismuh.ac.id, 3idrawahyuni@gmail.com
}

\begin{abstract}
Research aims to determine the effective measurement of operational cost control of variance operational cost in regional office VI PT. Pegadaian (Persero) Makassar. The approach used in this research is a qualitative approach. The research object is located in regional office VI PT. Makassar pawnshop (Persero) with the address Jl. Kumala Raya No. 7, Makassar, South Sulawesi 90223. The types of data used in this research are qualitative data, while the source of data obtained in this research is a secondary source. The data analysis methods used to test the hypothesis are using descriptive methods and analysis of the variance of operational costs. The results of this research show that in 2015 the realization of the cost of Rp 233.361.221. Exceeds the budget of the stipulated cost (unfavorable) of Rp. 223.058.122. As for the year 2016 the realization of the cost of Rp. 280.772 .516 not exceed from budget.
\end{abstract}

Keywords: Operating costs, cost control, cost analysis.

\begin{abstract}
Abstrak
Penelitian ini bertujuan untuk mengetahui pengukuran efektivitas pengendalian biaya operasional terhadap varians biaya operasional pada Kantor Wilayah VI PT. Pegadaian (Persero) Makassar. Pendekatan yang digunakan dalam penelitian ini adalah pendekatan kualitatif. Objek Penelitian ini berlokasi di Kantor Wilayah VI PT.Pegadaian (Persero) Makassar dengan alamat Jl. Kumala Raya No.7, Makassar, Sulawesi Selatan 90223. Adapun jenis data yang digunakan dalam penelitian ini adalah data kualitatif, sedangkan Sumber data yang diperoleh dalam penelitian ini adalah sumber sekunder.Adapun metode analisis data yang digunakan untuk menguji hipotesis adalah menggunakan metode deskriptif dan analisis varians biaya operasional. Hasil penelitian ini menunjukkan bahwa Pada tahun 2015 realisasi biaya sebesar Rp233.361.221.melebihi dari anggaran biaya yang telah ditetapkan (unfavorable) sebesar Rp.223.058.122. Sedangkan untuk tahun 2016 realisasi biaya Rp.280.772.516 tidak melebihi dari anggaran yang telah ditetapkan(favorable) yaitu sebesar Rp.292.662.376.
\end{abstract}

Kata Kunci: Biaya Operasional, Pengendalian Biaya, Analisis Biaya. 


\section{PENDAhuluan}

Tujuan dari suatu perusahaan pada umumnya adalah meningkatkan kualitas produk dan jasa, mendapatkan pangsa pasar yang ditargetkan, serta memperoleh laba maksimal. Mengingat pentingnya masa depan perusahaan agar dapat mempertahankan kelangsungan hidupnya untuk terus berkembang memerlukan adanya suatu perencanaan yang matang dan pengendalian yang efektif terhadap biaya yang akan dikeluarkan dalam kegiatan operasionalnya. Pentingnya pengendalian biaya yang efektif dalam kegiatan operasionalnya membantu perusahaan dalam menganalisis varians biaya operasional yang terjadi. Varians atau selisih adalah perbedaan antara suatu rencana atau target dari suatu hasil Witjaksono (2013).

Namun pada dasarnya biaya yang dikeluarkan perusahaan sering kali terjadi kelebihan dan kekurangan biaya dalam aktivitasnya. Dengan terjadi kelebihan dan kekurangan biaya maka akan mengakibatkan efisiensi tidak akan tercapai sehingga menghambat masalah pencapaian suatu tujuan dalam perusahaan. Dengan demikian dapat dikatakan bahwa biaya merupakan faktor utama dalam menjalankan perusahaan baik perusahaan perdagangan, industri maupun perusahaan jasa. Disamping itu juga merupakan salah satu faktor yang penting dalam pengambilan keputusan manajemen, sehingga diperlukan suatu teknik/ strategi untuk meminimalkan biaya tersebut. Untuk dapat melaksanakan hal tersebut suatu organisasi perusahaan perlu untuk menyusun urutan prioritas pencapaiannya dalam mencapai tujuan, baik yang bersifat jangka pendek maupun jangka panjang.

Salah satu bentuk penjabaran sarana mencapai tujuan perusahaan bentuk suatu periode tertentu adalah sangat diperlukan adanya anggaran yang matang dalam pelaksanaan dan pengendalian biaya secara efektif dan efisien agar hal tersebut dapat terwujud, maka anggaran dan realisasinya harus mendapat pengawasan yang terkoordinasi dan terencana dengan baik, anggaran tersebut harus dapat dijadikan suatu standar atau anggaran yang kemudian dibandingkan dengan pelaksanaan yang sudah terealisasikan dengan benar. Anggaran disusun dapat berdasarkan pada hasil kerja periode yang lalu maupun perkembangan keinginan masyarakat. PT.Pegadaian (Persero) merupakan salah satu lembaga formal di Indonesia yang bergerak dibidang jasa yang berdasarkan hukum diperbolehkan melakukan pembiayaan dengan bentuk penyaluran kredit atas dasar hukum gadai. Pada setiap kegiatan yang dilakukan oleh PT. Pegadaian (Persero) adalah melakukan pembiayaan, kegiatan-kegiatan pembiayaan tersebut berupa penyaluran dana atau kegiatan menawarkan/pemberian sejumlah produk jasa non gadai kepada nasabahnya. Dalam kegiatannya pemberian produk jasa pegadaian dikenakan biaya operasional, karena pada setiap kegiatannya terdapat biaya-biaya tertentu yang diperlukan dalam menjalankan kegiatan operasinya. Pengendalian terhadap biaya yang akan dikeluarkan untuk menjalankan kegiatan operasinya harus bisa dikendalikan, agar jumlah realisasi pada setiap biaya tidak melebihi anggaran, sehingga setiap tujuan yang diharapkan perusahaan dapat tercapai.

\section{TINJUAN PUSTAKA}

\section{Biaya}

Menurut Radiks (2006), Tentative Set of Broad Acccounting prinples Enterprise, biaya dinyatakan sebagai harga pertukaran atau pengorbanan yang dulakukan untuk memperoleh manfaat. Bila istilah biaya digunakan secara spesifik, istilah ini dilengkapi menunjukkan objek yang bersangkutan, misalnya biaya langsung, biaya konversi, biaya tetap, biaya variabel, biaya standar, biaya differensial, biaya kesempatan dan sebagainya. Setiap perlengkapan mempunyai arti dalam menghitung dan mengukur biaya yang akan berguna bagi pimpinan dalam mencapai sasaran perencanaan dan pengawasan .

\section{Biaya Operasional}

Biaya operasional atau biaya komersial merupakan biaya yang memiliki peran besar dalam mempengaruhi keberhasilan perusahaan mencapai tujuannya, yaitu memperoleh laba usaha. Tanpa aktivitas operasional yang terarah maka seluruh produk yang dihasilkan tidak akan memiliki manfaat apapun bagi perusahaan. Secara umum, biaya operasional dibagi ke dalam 2 kelompok besar, yaitu biaya pemasaran (marketing cost) dan biaya administrasi dan umum Dewi (2009)

\section{Anggaran Biaya Operasional}

Menurut Rudianto (2009) "Anggaran biaya operasional adalah semua rencana pengeluaran yang berkaitan dengan distribusi dan penjualan 
produk perusahaan serta pengeluaran untuk menjalankan roda organisasi". Anggaran operasional (operational budget) merupakan anggaran yang bertujuan untuk menyusun anggaran laba rugi Nafarin (2007). Dimana anggaran laba rugi itu sendiri adalah anggaran berupa daftar yang disusun secara bersistem tentang dapatan, beban, serta laba (rugi) yang diperoleh suatu perusahaan selama periode tertentu.

Strategi, perencanaan, dan anggaran Horngren (2008)

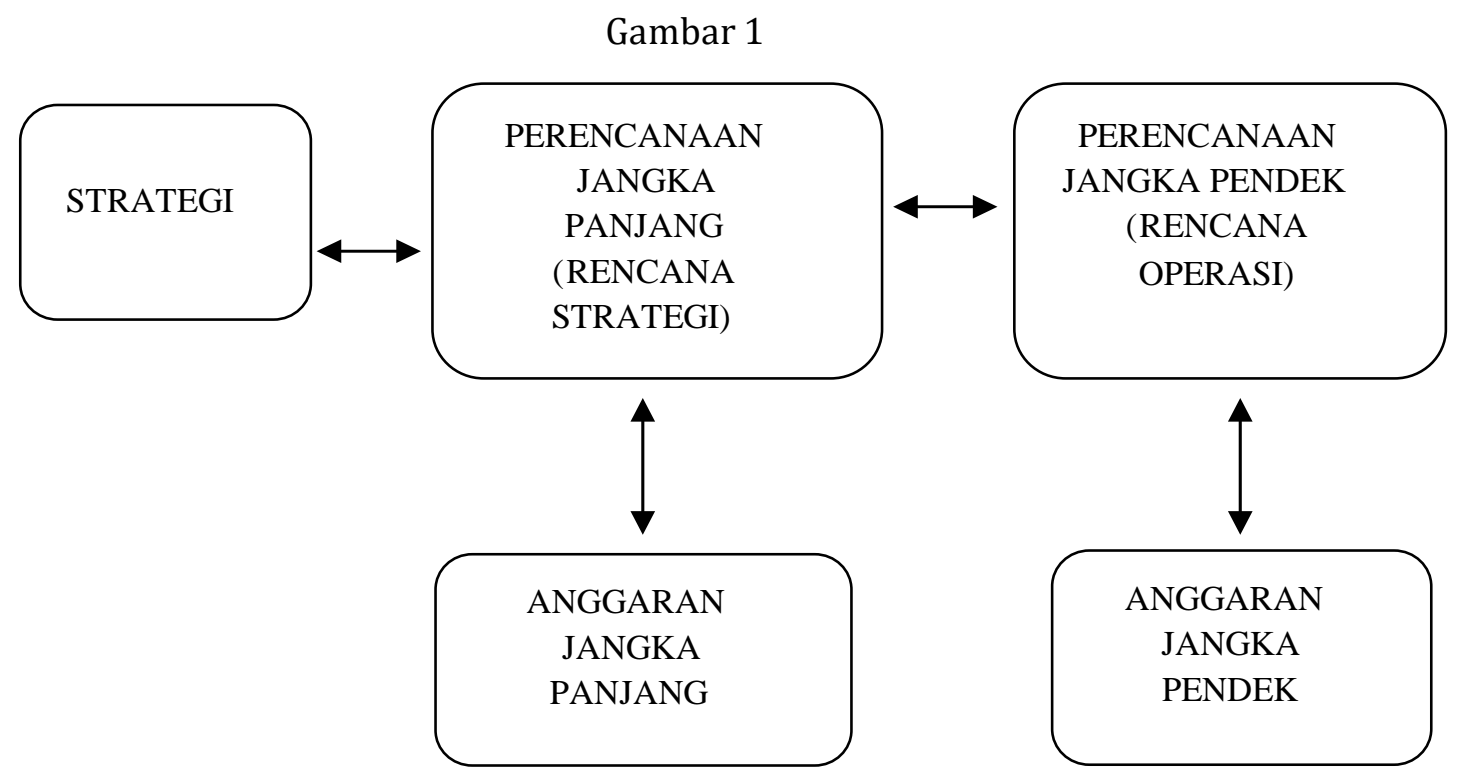

\section{Analisis Varians}

Analisis variansi atau analisis selisih dimaksudkan untuk tujuan perencanaan atau pengendalian manajerial dalam konteks program Perencanaan dan Pengendalian Laba (LPP) yang komprehensif. Menurut Harahap (2009) pengertian analisis variansi adalah sebagai berikut: "Analisis variansi adalah analisis yang dilakukan untuk mengetahui ada tidaknya penyimpangan realisasi dibandingkan dengan anggarannya". Berdasarkan pernyataan tersebut diatas, dapat disimpulkan bahwa suatu selisih dapat dianggap menguntungkan atau tidak menguntungkan.

\section{METODE}

\section{Pendekatan Penelitian}

Pendekatan yang digunakan dalam penelitian ini adalah pendekatan kualitatif. Objek Penelitian ini berlokasi di Kantor Wilayah VI PT.Pegadaian (Persero) Makassar dengan alamat Jl. Kumala Raya No.7, Makassar, Sulawesi Selatan 90223. Adapun jenis data yang digunakan dalam penelitian ini adalah data kualitatif, sedangkan Sumber data yang diperoleh dalam penelitian ini adalah sumber sekunder.

\section{Metode Analisis Data}

Adapun metode analisis data yang digunakan untuk menguji hipotesis adalah menggunakan metode deskriptif dan analisis varians biaya operasional

a. Metode Deskriptif.

Metode deskriptif adalah metode penelitian yang hanya mendeskripsikan tentang analisis biaya operasional dalam mengukur efektifitas pengendalian biaya operasional. Penelitian dilakukan pada kondisi yang alamiah langsung ke sumber data, dan data yang terkumpul berupa struktur organisasi, job description, buku saku produk pegadaian, dan laporan realisasi rencana kerja dan anggaran Kantor Wilayah VI PT.Pegadaian (Persero) Makassar tahun 2015 dan 2016.

b. Analisis Varians Biaya Operasional

Witjaksono (2013) varians atau selisih adalah perbedaan antara suatu rencana atau target dan suatu hasil. 
1) Untuk Varians Biaya Operasional Tahun 2015 dan tahun 2016: Varians = Realisasi tahun $\mathrm{xxx}-$ Anggaran tahun $\mathrm{xxx}=\mathrm{Rp} . \mathrm{Xxx}$

2) Untuk persentase realisasi biaya operasional Tahun 2015 dan 2016:

$$
\begin{aligned}
\% & =\frac{\text { realisasi tahun } \mathrm{xxx}}{\text { anggaran tahun } \mathrm{xxx}} \times 100 \% \\
& =x x x
\end{aligned}
$$

3) Untuk selisih menguntungkan/Favorable variance Anggaran > Realisasi

4) Untuk selisih merugikan /Unfavorable variance Anggaran < Realisasi

\section{HASIL DAN PEMBAHASAN}

\section{Hasil Penelitian}

Realisasi Rencana Kerja dan Anggaran Biaya Operasional Kantor Wilayah VI PT. Pegadaian (persero) Makassar. Anggaran biaya operasional Kantor Wilayah VI PT.Pegadaian (Persero) Makassar meliputi 5 pos anggaran, yaitu biaya bunga dan provisi, biaya pegawai, biaya administrasi, biaya umum, dan biaya pendidikan dan latihan.

Tabel 1. Biaya Operasional Kantor Wilayah VI PT. Pegadaian (persero) Makassar

\begin{tabular}{cccccc}
\hline \multirow{2}{*}{$\begin{array}{l}\text { Kode } \\
\text { Perk }\end{array}$} & \multirow{2}{*}{ Uraian } & \multicolumn{2}{c}{ Tahun 2015 } & \multicolumn{2}{c}{ Tahun 2016 } \\
\cline { 3 - 6 } 511 & & Anggaran & Realisas i & Anggaran & Realisasi \\
\hline 512 & Biaya bunga dan provisi & 118.175 .458 & 129.672 .551 & 149.413 .429 & 141.401 .474 \\
\hline 513 & Biaya pegawai & 58.584 .047 & 68.423 .114 & 82.524 .114 & 87.098 .063 \\
\hline 514 & Biaya administrasi \& pemasaran & 6.627 .196 & 6.069 .196 & 6.457 .689 & 5.523 .576 \\
\hline 515 & Biaya umum & 39.415 .321 & 29.170 .817 & 53.813 .044 & 46.606 .328 \\
\hline
\end{tabular}

Total anggaran biaya operasional pada tahun 2015 adalah Rp.223.058.122 dengan total realisasi Rp.233.361.221, dan pada tahun 2016 total anggaran biaya operasional adalah $\mathrm{Rp}$. 292.662.376 dengan total realisasi Rp. 280.772.516.

\section{Proses Penyusunan Laporan Realisasi Rencana Kerja dan Anggaran Biaya Operasional}

Prosedur yang digunakan dalam penyusunan anggaran biaya operasional pada Kantor Wilayah VI PT. Pegadaian (Persero) Makassar menggunakan metode dari bawah ke atas (Bottom Up) yaitu anggaran di susun sendiri oleh manajemen level bawah untuk melaksanakan program kerja perusahaan sesuai dengan kondisi dan kebutuhan perusahaan dan selanjutnya diserahkan ke manajemen atas untuk melaporkan setiap kegiatan dan realisasi anggaran kerja dari perusahaan, serta permohonan persetujuan dari setiap biaya operasional yang akan ditetapkan.

\section{Pembahasan}

\section{Penyebab Terjadinya Varians Biaya Operasional}

Berdasarkan hasil analisis varians yang dilakukan pada realisasi dan anggaran biaya operasional tahun 2016 dari tabel 1 maka diketahui biaya-biaya yang menyebabkan penyimpangan (varians) pada biaya operasional sebagai berikut.

a. Biaya Bunga dan Provisi

Pada tahun 2015 dan 2016 biaya bunga dan provisi terjadi kenaikan pada suku bunga pinjaman dalam kegiatan transaksinya, sehingga total realisasi biaya bunga dan provisi lebih dari $100 \%$ atau melebihi anggaran yang ditetapkan.

b. Biaya Pegawai

Pada tahun 2015 dan 2016 adanya kenaikan tarif gaji atau kenaikan tunjangan fungsional, serta adanya penambahan biaya untuk uang perumahan pegawai. Total realisasi untuk biayabiaya tersebut lebih dari $100 \%$ atau melebihi anggaran yang ditetapkan.

c. Biaya Administrasi dan Pemasaran

Pada tahun 2015 dan 2016 biaya administrasi dan pemasaran dipengaruhi oleh kondisi dan situasi kerja perusahaan dimana meningkatnya kebutuhan kantor untuk biaya pencetakan SBK, biaya alat tulis kantor, dan biaya perlengkapan kantor sehingga memerluka pengadaan barang baru. Total realisasi dari biaya-biaya tersebut lebih dari $100 \%$ atau melebihi anggaran yang ditetapkan.

d. Biaya Umum

Pada tahun 2015 dan 2016 biaya umum dipengaruhi oleh beberapa faktor seperti biaya listrik, biaya perjalanan dinas, dan biaya sewa. Total realisasi dari ketiga biaya tersebut lebih dari $100 \%$ atau melebihi anggaran yang ditetapkan. 
e. Biaya Pendidikan dan Pelatihan

Pada tahun 2016 terjadi kenaikan pada biaya diklat internal lebih dari $100 \%$ atau melebihi dari anggaran yang ditetapkan.

\section{Usaha Perbaikan Terhadap Varians Biaya Operasional}

Berikut ini usaha-usaha perbaikan Kantor Wilayah VI PT.Pegadaian (Persero) Makassar terhadap penyimpangan biayaoperasional yang terjadi, agar pengendalian biaya perusahaan bisa berjalan efektif.

a. Biaya Usaha

Pada biaya bunga dan provisi terjadi kenaikan suku bunga pinjaman bank pada kegiatan transaksi yang dilakukan.Tindakan yang harus dilakukan mengendalikan atau mengurangi kegiatan pinjaman bank, agar supaya biaya bunga dan provisi turun.

b. Biaya Pegawai

Menyangkut biaya pegawai adanya kenaikan tarif gaji atau kenaikan tunjangan fungsional, serta adanya penambahan biaya untuk uang perumahan pegawai.Pihak perusahaan harus menetapkan kembali kebijakan dalam menaikan gaji atau tunjangan.Kenaikan gaji atau tunjangan sebaiknya diberikan kepada pegawai yang kualitas mutu kerjanya baik, dilihat dari lamanya masa kerja, atau golongan/jabatan yang dimiliki dari setiap pegawai yang ada di perusahaan.Sehingga perusahaan tidak melakukan pemborosan.

c. Biaya Administrasi \& Pemasaran

Untuk biaya administrasi dan pemasaran dipengaruhi oleh kondisi dan situasi kerja perusahaan dimana meningkatnya kebutuhan kantor untuk biaya pencetakan SBK, biaya alat tulis kantor, dan biaya perlengkapan kantor sehingga memerlukan pengadaan barang baru. Perusahaan harus bisa memilih mana yang menjadi kebutuhan mendesak untuk dibeli atau mengurangi pembelian barang/inventaris kantor dalam jumlah yang besar.

d. Biaya Umum

Biaya umum dipengaruhi oleh beberapa faktor seperti biaya listrik, biaya perjalanan dinas, dan biaya sewa.Usaha perbaikan yang harus dilakukan perusahaan mengurangi pemakaian biaya yang terlalu banyak.

e. Biaya Pendidikan \& Pelatihan

Pada biaya pendidikan dan pelatihan terjadi kenaikan pada biaya diklat internal. Perusahaan mengeluarkan biaya sesuai dengan kebutuhan yang diperlukan selama berlangsungnya proses kegiatan tersebut.

\section{Efektivitas Pengendalian Biaya Operasional}

Tolak ukur yang digunakan perusahaan untuk mengukur efektifnya pengendalian terhadap biaya adalah membandingkan antara biaya yang sesungguhnya terjadi dengan biaya aktual sesuai dengan anggaran yang sudah ditetapkan.Dari hasil analisis varians biaya operasional di Kantor Wilayah VI PT. Pegadaian (Persero) Makassar, terjadi penyimpangan biaya baik itu penyimpangan tidak menguntungkan (unfavorable) atau penyimpangan menguntungkan (favorable). Namun untuk pengendalian terhadap biaya operasional diperusahaan sudah efektif, karena adanya usaha perbaikan yang dilakukan perusahaan pada setiap biaya yang terjadi penyimpan..

\section{KESIMPULAN DAN SARAN}

\section{Kesimpulan}

Berdasarkan pembahasan hasil penelitian, maka penulis dapat menarik kesimpulan bahwa

a. Dalam proses penyusunan anggaran di Kantor Wilayah VI PT.Pegadaian (Persero) Makassar sudah baik, setiap bagian turut berpartisipasi dalam penyusunan anggaran. Dan untuk pengendalian terhadap biaya operasional diperusahaan pun sudah efektif, karena adanya usaha perbaikan yang dilakukan perusahaan pada setiap biaya yang terjadi penyimpangan.

b. Pada tahun 2015 realisasi biaya sebesar Rp233.361.221.melebihi dari anggaran biaya yang telah ditetapkan(unfavorable) sebesar Rp.223.058.122. Sedangkan untuk tahun 2016 realisasi biaya Rp.280.772.516 tidak melebihi dari anggaran yang telah ditetapkan(favorable) yaitu sebesar Rp.292.662.376.

\section{Saran}

Berdasarkan hasil penelitian dan kesimpulan di atas, maka diberikan saran sebagai berikut:

a. Perusahaan harus lebih meningkatkan pengendalian terhadap biaya, agar jumlah realisasi biaya bisadikendalikan dan tidak melebihi anggaran yang telah ditetapkan sebelumnya.

b. Diharapkan perusahaan dapat melakukan kebijakan dalam pengurangan biaya, membuat prioritas rencanakerja, mempertimbangkan kebutuhan yang terjadi 
berdasarkan anggaran yang tersedia, sertamengevaluasi kebutuhan dan anggaran.

\section{REFERENSI}

Ambarwati, M. J. dan T. (2005). Anggaran Perusahaan (Edisi Pert). Malang: UNM Press.

Blocher, E. J. (2005). Cost management: a strategic emphasis. et al. Dewi, M. S. (2009). Akuntansi Manajemen, Modul 9. Jakarta.

F., Moh. A. Husein, H. (2009). Sistem Pengendalian Manajemen. Yogyakarta: YKPN.

Harahap, S. S. (2009). Teori Akuntansi Edisi Revisi. Jakarta: PT. Raja Grafindo Persada.

Horngren, C. T. (2008). Akuntansi Biaya (Edisi 7). Jakarta: PT. Indeks.

Ikhsan, A. (2009). Akuntansi Manajemen Perusahaan Jasa. Yogyakarta: Graha Ilmu.

Kartadinata. (2011). Akuntansi Dan Analisis Biaya (Edisi Keti). Jakarta: PT. Rineka Cipta.

Karyoso. (2005). Manajemen Perencanaan dan Penganggaran. Jakarta: PTIK PRESS \& Restu Agung.

Kuncoro, M. (2005). Metode Riset Untuk Bisnis Dan Ekonomi Bagaimana Meneliti Dan Menulis Tesis. Erlangga.

Mulyadi. (2005). Akuntansi Biaya (Edisi Keli). Yogyakarta: UPP AMP YKPN.

Musyiridi. (2008). Akuntansi Biaya (Edisi Pert). Bandung: Refika Aditama.

Nafarin. (2007). Penggangaran Perusahaan (Edisi Keti). Jakarta: Salemba Empat.

Prawironegoro. (2008). Penganggaran Perusahaan. Jakarta: Mitra Wacana Media.

Radiks, P. dan. (2006). Tentative Set of Broad Acccounting prinples Enterprise.

Rudianto. (2009). Akuntansi Manajemen. Yogyakarta: Grasindo.

Sugiyono. (2010). Metode Penelitian Pendidikan (Pendekatan Kuantitatif, Kualitatif Dan R\&D.

Supriyono, R. (2005). Sistem Pengendalian Manajemen (Edisi Kedua). Yogyakarta: BPFE. Witjaksono, A. (2013). Akuntansi Biaya. (G. Ilmu, Ed.) (Edisi Revi). Yogyakarta.
Jurnal:

Christian Kainde (2013). Analisis Varians Dan Pertumbuhan Belanja Daerah Pada Pemerintahan Kota Bitung.

Fathor (2008). Pengendalian Biaya Operasional Guna Meningkatkan Laba Usaha Pada Koperasi Agro Niaga (KAN) Jabung Malang (Periode 2005-2007).

Febriyanti Kadir (2013). Varians Anggaran Dan Realisasi Anggaran Belanja Pada Pemerintahan Daerah Kabupaten Bone Bolango.

Jane Irene Watania (2013). Analisis Varians Biaya Operasional Dalam Mengukur Efektivitas Pengendalian Biaya Operasional PT. Pegadaian.

Jefry Katili (2013). Analisis Varians Biaya Operasional Dalam Mengukur Efektivitas Pengendalian Biaya Operasional Pada PT. Asuransi Jiwasraya (persero) Manado.

Nani Nurani (2009). Peranan Anggaran Biaya Operasional Sebagai Alat Pengendalian Menajemen Pada PT. Sariwangi AEA.

Novi Suprapti (2010). Analisis Variansi Antara Anggaran Pemberian Kredit Dan Realisasi Pemberian Kredit Pada Koperasi Pegawai RI RSUP Dr. Hasan Sadikin Bandung.

Octora Kurnia Goseldia (2009). Analisis Varian Pengaruh Interaksi Harga Dan Citra Merek Terhadap Keputusan Pembelian.

Sultan Iskandar (2014). Analisis Anggaran Biaya Operasional Sebagai Alat Pengendalian Biaya Pada Proyek Pembangunan Gedung Kantor Kejati SulSel (Studi Kasus PT. Hutama Karya (Persero) Wilayah V Makassar).

Suzi Suzana (2013). Analisis Pengendalian Biaya Operasional Pada CV. Cahaya Bina Lestari Banjarmasin. 